\title{
Peramalan Arus Kas dengan Pendekatan Time Series Menggunakan Support Vector Machine
}

\author{
Bella Audina ${ }^{1}$, Mohamat Fatekurohman ${ }^{2}$, dan Abduh Riski ${ }^{3}$ \\ 1,2,3 Jurusan Matematika, Universitas Jember \\ bellaaudina27@gmail.com
}

\begin{abstract}
Cash flow is a form of financial report that is used as a measure of the company success in the investment world. So that companies need to forecast the cash flow to manage their finances. Statistics can be applied for the forecasting of cash flow using the Support Vector Machine (SVM) method on the time series data. The aim of this research is to determine the optimal parameter pair model of the Radial Basic Function kernel and to obtain the forecasting results of cash flow using the SVM method on the time series data. The independent variable is needed the data on cash flow from operating income, expenditure and investment expenditure, sum of all cash flow. While the dependent variable is the financial condition based on the Free Cash Flow. The result of this research is a model with the best parameter pairs of the SVM tuning results with the greatest accuracy that is $75 \%$, $82 \%, 88 \%, 64 \%$ and the forecasting financial condition of PT Cakrawala for the next 16 months.
\end{abstract}

Keywords: cash flow, forecasting, time series, support vector machine.

\section{Pendahuluan}

Arus kas adalah bentuk laporan keuangan yang dijadikan tolok ukur keberhasilan perusahaan di dunia investasi, sehingga perusahaan perlu melakukan peramalan arus kas untuk mengatur keuangannya. Statistika dapat diaplikasikan pada peramalan arus kas dengan menggunakan metode peramalan (forecasting). Peramalan adalah pengolahan data di masa lalu dengan metode matematika untuk memperkirakan kejadian di masa yang akan datang [1]. Sebagian besar masalah peramalan melibatkan penggunaan data deret waktu (time series). Deret waktu adalah pengamatan rangkaian data yang diukur selama kurun waktu tertentu [2]. Pendekatan time series sangat baik digunakan untuk menyelesaikan data linier, sedangkan model data non-linier seperti data keuangan arus kas dapat diselesaikan dengan pendekatan Support Vector Machine (SVM). SVM merupakan salah satu metode yang dapat menyelesaikan masalah peramalan dan mampu mengatasi overfitting sehingga dapat meningkatkan akurasi hasil prediksi. Dalam pemodelan SVM sangat penting memilih tipe kernel terbaik untuk menentukan kinerja prediksi time series. Kernel Radial Basic Function (RBF) dinilai lebih baik diterapkan jika ketergantungan antara data terdahulu dengan data sekarang bersifat non-linier [3]. Pendekatan time series baik dalam pemodelan linier dan SVM dengan kernel RBF bisa digunakan dalam pemodelan non- 
linier, maka penelitian ini bertujuan untuk menentukan hasil peramalan arus kas dengan menggunakan metode SVM pada data time series.

\section{Tinjauan Pustaka}

2.1. Arus Kas. Menurut Kamus Besar Bahasa Indonesia (KBBI), arus kas adalah pemasukan dan pengeluaran dana perusahaan berdasarkan harian, mingguan, atau dalam rentang waktu tertentu. Laporan arus kas disusun untuk membantu tugas manajer keuangan perusahaan dan memberikan informasi mengenai perubahan kas perusahaan dengan relevan dalam periode waktu tertentu. Berdasarkan keperluan manajerial, laporan arus kas dibagi menjadi tiga kategori yaitu arus kas dari aktivitas operasi, investasi, dan pendanaan [4].

Arus kas aktivitas operasi diperoleh dari transaksi dan peristiwa lain yang memengaruhi penetapan laba atau rugi bersih perusahaan. Arus kas aktivitas investasi diperoleh dari kegiatan investasi yaitu aktiva tetap. Arus kas aktivitas pendanaan adalah arus kas yang berasal dari modal dan pinjaman perusahaan.

2.2. Peramalan (Forecasting). Peramalan atau forecasting adalah perkiraan dengan menggunakan teknik statistika dalam bentuk gambaran masa depan berdasarkan pengolahan angka secara historis. Terdapat dua pendekatan umum yang dilakukan pada saat peramalan yaitu metode kualitatif dan kuantitatif. Peramalan metode kuantitatif terdiri dari model deret waktu dan model asosiatif. Peramalan yang akan digunakan pada penelitian ini yaitu metode SVM dengan sistem klasifikasi. Salah satu metode yang dapat digunakan untuk mengukur kinerja klasifikasi yaitu confusion matrix.

Pada confusion matrix terdapat empat istilah sebagai representasi hasil klasifikasi yaitu True Positive (TP) yang merepresentasikan kelas positif terdeteksi benar, True Negative (TN) merepresentasikan data kelas negatif yang terdeteksi benar, False Positive (FP) merepresentasikan jumlah kelas negatif yang terdeteksi sebagai kelas positif dan False Negative (FN) merepresentasikan data kelas positif yang terdeteksi sebagai kelas negatif. Performa klasifikasi dapat dihitung nilai akurasinya. Adapun perhitungan menentukan besar nilai akurasi sebagai berikut [5].

$$
\text { Akurasi }=\frac{T P+T N}{T P+T N+F P+F N} 100 \%
$$

2.3. Deret Waktu (Time Series). Deret waktu adalah salah satu pemodelan dalam penelitian dinamis yang bertujuan untuk mengumpulkan dan mempelajari pengamatan 
deret waktu sebelumnya. Hal ini bertujuan untuk mengembangkan model yang menggambarkan struktur yang melekat dari deret tersebut. Deret waktu dibedakan menjadi analisis deret waktu dan peramalan deret waktu. Terdapat dua hal yang harus diperhatikan untuk kesempurnaan model deret waktu yang dihasilkan yaitu adanya autokorelasi dan data harus stasioner.

Uji stasioneritas bertujuan untuk menguji konsistensi pergerakan data deret waktu. Salah satu jenis uji stasioneritas yaitu uji Augmented Dickey Fuller (ADF). Uji ADF dilakukan dengan menggunakan paket " $u r . d f$ ” yang sudah disediakan oleh aplikasi R-Studio. Adapun prosedur uji stasioneritas sebagai berikut.

Hipotesis:

$H_{0}$ : data tidak stasioner

$H_{1}$ : data stasioner

Statistik uji antara nilai statistik- $t$ dan nilai kritis ADF sebagai berikut [6].

1. Jika nilai statistik- $t<$ nilai kritis, maka tolak $H_{0}$

2. Jika nilai statistik- $t>$ nilai kritis, maka terima $H_{0}$ Adapun persamaan umum uji stasioneritas sebagai berikut.

$$
\Delta Y_{t}=\beta_{1}+\beta_{2} t+\delta Y_{t-1}+\alpha_{i} \sum_{i=1}^{m} \Delta Y_{t-1}+u_{t}
$$

dengan

$Y_{\mathrm{t}} \quad$ : data time series

$t \quad:$ trend deterministic

$\beta_{1}, \beta_{2} \quad$ : intersep / konstanta

$m \quad$ : panjang lag

$\delta \quad: 0$ (jika memiliki akar unit) dan $\delta: 1$ (jika tidak memiliki akar unit)

2.4. Support Vector Machine (SVM) pada Time Series. SVM adalah salah satu metode machine learning yang digunakan untuk memprediksi klasifikasi menggunakan konsep pencarian hyperplane dengan margin maksimum. SVM mudah diaplikasikan pada kasus data non linier dengan menggunakan konsep kernel pada ruang kerja berdimensi tinggi. Salah satu contoh fungsi kernel yang sering digunakan yaitu Radial Basic Function (RBF). Adapun persamaan umum fungsi kernel sebagai berikut.

$$
K\left(\overrightarrow{x_{i}}, \overrightarrow{x_{j}}\right)=\phi\left(\overrightarrow{x_{i}}\right) \cdot \phi\left(\overrightarrow{x_{j}}\right)
$$


dimana $\phi\left(\vec{x}_{i}\right)$ adalah fungsi data $x_{i}, \phi\left(\overrightarrow{x_{j}}\right)$ adalah fungsi data $x_{j}$, dan $j$ merupakan ruang vektor yang lebih tinggi dari $i$.

Fungsi kernel di atas dapat digunakan pada fungsi kernel RBF yaitu [7].

$$
K\left(\overrightarrow{x_{i}}, \overrightarrow{x_{j}}\right)=\exp \left(-\gamma\left\|\vec{x}_{i}-\vec{x}_{j}\right\|^{2}\right.
$$

dimana $x_{i}$ dan $x_{j}$ adalah sebuah data time series, sedangkan $\gamma$ adalah nilai kernel RBF yang optimal.

2.5. Metode Grid Search. Metode grid search digunakan untuk menentukan parameter optimal pada model SVM dengan melatih pasangan parameter yang menghasilkan akurasi terbaik. Penentuan parameter SVM terbaik dengan metode grid search menggunakan kernel trick. Adapun jenis kernel trick antara lain linier, polynomial, RBF, dan sigmoid. Jenis kernel trik yang digunakan dalam penelitian ini adalah kernel RBF. Jenis parameter yang digunakan pada SVM dengan kernel RBF yaitu cost $(c)$ dan gamma $(\gamma)$ dengan persamaan

$$
c, \gamma=\{i, j \mid i \in c \text { dan } j \in \gamma\}
$$

dengan

$i$ : anggota himpunan $c$

$j$ : anggota himpunan $\gamma$

2.6. K-Fold Cross Validation. Uji Cross-Validation (CV) merupakan salah satu metode statistika untuk mengevaluasi kinerja algoritma dimana data akan dipisahkan menjadi dua subset yaitu data proses pembelajaran dan data validasi. Berdasarkan ukuran dataset, CV dibagi menjadi beberapa jenis dan salah satunya $k$-fold crossvalidation. Salah satu model $k$-fold cross-validation yang sering digunakan yaitu 10 fold cross-validation. Penelitian [8] membuktikan bahwa 10 fold cross-validation mampu memberikan estimasi akurasi yang kurang bias dibandingkan dengan model lainnya. Penelitian [9] menghasilkan nilai akurasi terbesar yaitu $k=5$ atau 5 fold untuk hasil pengujian terbaiknya.

\section{Metode Penelitian}

Jenis data yang digunakan pada penelitian ini adalah data primer yang diambil langsung dari PT Cakrawala dalam beberapa periode terakhir. Data bersumber dari data arus kas selama 56 bulan terakhir menggunakan metode kuantitatif dengan penelitian 
survei. Variabel yang digunakan pada penelitian ini adalah sebagai berikut :

1. Variabel terikat $(Y)$ pada penelitian ini adalah kondisi keuangan arus kas perusahaan berdasarkan data Free Cash Flow.

2. Variabel bebas $(X)$ pada penelitian ini yaitu data keuangan pemasukan arus kas operasi, pengeluaran arus kas operasi, pengeluaran arus kas investasi, dan jumlah dari ketiga jenis arus kas tersebut.

Adapun langkah-langkah yang dilakukan dalam penelitian ini sebagai berikut :

1. Studi literatur dengan cara mencari sumber referensi dari jurnal, skripsi, dan buku.

2. Pengambilan dan pengolahan data ke dalam bentuk matriks melalui program excel.

3. Pre-processing data dengan dilakukan uji stasioneritas menggunakan uji ADF.

4. Pembagian data yang meliputi data pelatihan (training) dan data pengujian (testing) dengan persentase 70:30 dan 80:20 menggunakan paket "caret" dengan function createDataPartition.

5. Pemodelan dengan SVM dimulai dari training SVM untuk mendapatkan model SVM dengan $k=5$ dan $k=10$.

6. Melakukan tuning parameter untuk mencari model SVM dengan pasangan parameter terbaik dari hasil uji data training.

7. Melakukan pengujian model SVM terbaik pada data testing.

8. Melakukan analisis hasil dan menentukan hasil prediksi atau peramalan data keuangan arus kas beberapa periode selanjutnya.

\section{Hasil dan Pembahasan}

4.1. Analisis Variabel. Variabel yang digunakan dalam penelitian ini yaitu variabel bebas $(X)$ dan variabel terikat $(Y)$. Variabel bebas $(Y)$ berupa pemasukan arus kas operasi, pengeluaran arus kas operasi, pengeluaran arus kas investasi, dan jumlah dari ketiga arus kas tersebut. Data pengeluaran arus kas operasi meliputi biaya listrik, Wi-Fi, PDAM, parkir, tol, materai, ATK, ongkos kirim, pajak, zakat, makan siang, dan gaji karyawan. Data pengeluaran arus kas investasi meliputi biaya pembelian kendaraan (mobil dan sepeda motor), mebel, sekat kantor, komputer, mesin jahit, AC dan pembayaran BPJS ketenagakerjaan. Variabel terikat berisi data Free Cash Flow (FCF) yang dimiliki PT Cakrawala dengan transformasi output 0 untuk kelas kondisi keuangan buruk dan 1 untuk kelas kondisi keuangan baik. Data diinputkan ke dalam program R-Studio dengan paket 
"read.csv".

4.2. Uji Stasioneritas Data. Data yang telah diinputkan ke dalam program $R$ Studio akan dikelompokkan menjadi empat variabel yaitu pemasukan_operasi mendefinisikan data pemasukan arus kas operasi, pengeluaran_operasi mendefinisikan data pengeluaran arus kas operasi, pengeluaran_investasi mendefinisikan data pengeluaran arus kas investasi, dan data_FCF mendefinisikan data FCF. Kemudian masing-masing data akan diuji kestasioneritasannya dan hasilnya dapat dilihat pada Tabel 1.

Tabel 1. Hasil Uji Stasioneritas Data

\begin{tabular}{|c|c|c|c|c|c|c|}
\hline \multirow{2}{*}{ Variabel } & \multirow{2}{*}{$p$-value } & \multirow{2}{*}{ Statistik- $t$} & \multicolumn{3}{|c|}{ Nilai Kritis ADF } & \multirow{2}{*}{$\begin{array}{c}\text { Keputusan } \\
\text { Hipotesis }\end{array}$} \\
\hline & & & $1 \%$ & $5 \%$ & $10 \%$ & \\
\hline $\begin{array}{c}\text { Pemasukan_ } \\
\text { operasi }\end{array}$ & $1,724 \times 10^{-8}$ & $-4,4692$ & & & & Stasioner \\
\hline $\begin{array}{c}\text { Pengeluaran_ } \\
\text { operasi }\end{array}$ & $3,145 \times 10^{-5}$ & $-3,4387$ & & & & Stasioner \\
\hline $\begin{array}{c}\text { Pengeluaran_ } \\
\text { investasi }\end{array}$ & $4,776 \times 10^{-6}$ & $-3,6209$ & $-3,51$ & $-2,89$ & $-2,58$ & Stasioner \\
\hline Arus_kas & $2,317 \times 10^{-8}$ & $-4,613$ & & & & Stasioner \\
\hline Data_FCF & $7,301 \times 10^{-7}$ & $-4,3844$ & & & & Stasioner \\
\hline
\end{tabular}

Tabel 1 menunjukkan bahwa semua variabel data stasioner karena nilai statistik- $t<$ nilai kritis ADF sehingga keputusan hipotesis yaitu tolak $H_{0}$ dan terima $H_{1}$. Data dengan variabel pemasukan_operasi, pengeluaran_investasi, arus_kas dan data_out stasioner pada taraf signifikan $1 \%, 5 \%$, dan $10 \%$. Sedangkan variabel pengeluaran_operasi stasioner pada taraf signifikan 5\% dan $10 \%$.

4.3. Peramalan SVM. Pada penelitian ini dibentuk tiga data frame dari penggabungan masing-masing variabel bebas dengan variabel terikat. Selanjutnya masing-masing data frame akan dipartisi menjadi $70 \%$ data training dan $30 \%$ data testing serta $80 \%$ data training dan $20 \%$ data testing. Pembagian data menggunakan paket "caret" yang sudah disediakan oleh program R-Studio dan menghasilkan 40 data training dan 16 data testing serta 45 data training dan 11 data testing. 
4.3.1. Peramalan SVM Data Training. Peramalan SVM pada data training menggunakan paket "e1071" dan metode $k$-fold cross validation dengan nilai $k$ sebesar 5 dan 10. Hasil perhitungan peramalan data pemasukan operasi menghasilkan tingkat akurasi sebesar 85\% untuk 40 data training dan 84,44\% untuk 45 data training. Sedangkan hasil perhitungan peramalan data pengeluaran operasi menghasilkan tingkat akurasi sebesar $85 \%$ untuk 40 data training dan $82,22 \%$ untuk 45 data training. Hasil perhitungan peramalan data pengeluaran investasi menghasilkan tingkat akurasi sebesar $82,5 \%$ untuk 40 data training dan $84,44 \%$ untuk 45 data training. Dan hasil perhitungan jumlah arus kas menghasilkan tingkat akurasi sebesar $80 \%$ untuk 40 data training dan $86,67 \%$ untuk 45 data training.

4.3.2. Pemodelan dan Penentuan Nilai Parameter. Ranges nilai yang digunakan untuk parameter cost sebesar $2^{-5}, 2^{-4}, 2^{-3}, \ldots, 2^{13}, 2^{14}, 2^{15}$ dan parameter gamma sebesar $2^{-15}, 2^{-14}, 2^{-13}, \ldots, 2^{1}, 2^{2}, 2^{3}$. Ranges parameter tersebut ditentukan berdasarkan ranges yang sering digunakan dalam penelitian secara umum [10]. Penentuan nilai parameter pada penelitian ini menggunakan perpaduan metode grid search dan $k$-fold cross validation yang disebut juga tuning SVM. Tuning dilakukan sebanyak lima kali, kemudian dari hasil tuning dipilih pasangan parameter dengan nilai error terkecil. Pasangan parameter terbaik pada setiap data dapat dilihat pada Tabel 2.

Tabel 2. Pasangan Parameter Terbaik Setiap Data

\begin{tabular}{ccccc}
\hline \multirow{2}{*}{ Variabel } & \multirow{2}{*}{ Fold } & \multicolumn{2}{c}{ Nilai Parameter } & \multirow{2}{*}{ Nilai Error } \\
\cline { 3 - 4 } & & Cost & Gamma & \\
\hline Pemasukan_operasi & 5 & 64 & 1 & 0,1494876 \\
& 10 & 4 & 2 & 0,1492745 \\
Pengeluaran_operasi & 5 & 1024 & 0,125 & 0,233167 \\
Pengeluaran_investasi & 10 & 0,5 & 2 & 0,2483137 \\
& 5 & 64 & 4 & 0,1326296 \\
Arus_kas & 10 & 128 & 4 & 0,1236937 \\
& 5 & 512 & 0,0625 & 0,1256163 \\
& 10 & 4096 & 0,03125 & 0,1221944 \\
\hline
\end{tabular}

Dari hasil Tabel 2 hanya akan dipilih satu model SVM saja untuk meramalkan data arus kas. Sehingga model SVM untuk pemasukan_operasi menggunakan 10 fold dengan nilai parameter cost sebesar 4 dan gamma sebesar 2, pengeluaran_operasi 
menggunakan 5 fold dengan nilai parameter cost sebesar 1024 dan gamma sebesar 0,125, dan pengeluaran_investasi menggunakan 10 fold dengan nilai parameter cost sebesar 128 dan gamma sebesar 4, serta arus_kas menggunakan 10 fold dengan nilai parameter cost sebesar 4096 dan gamma sebesar 0,03125.

4.3.3. Peramalan Data Testing. Pengujian ini dilakukan pada setiap data arus kas dengan jumlah data testing yang berbeda yaitu sebanyak 16 data untuk pemasukan_operasi dan pengeluaran_operasi serta 11 data untuk pengeluaran_investasi. Pengujian data testing bertujuan untuk mengetahui tingkat akurasi model SVM sebelum model tersebut digunakan untuk meramalkan data arus kas. Model SVM dengan metode 10 fold untuk pemasukan_operasi memberikan kemampuan peramalan sebesar $75 \%$, pengeluaran_investasi mampu memberikan kemampuan peramalan sebesar $82 \%$. Sedangkan model SVM dengan metode 5 fold untuk pengeluaran_operasi memberikan kemampuan peramalan sebesar $88 \%$ dan model SVM dengan metode 10 fold untuk arus_kas memberikan kemampuan peramalan sebesar 64\%. Setelah mengetahui tingkat akurasi, selanjutnya dilakukan peramalan untuk mengetahui kondisi keuangan arus kas beberapa bulan selanjutnya menggunakan model SVM terbaik. Hasil peramalan dapat dilihat pada Tabel 3 dan 4 .

Tabel 3. Hasil Peramalan Setiap Data Arus Kas

\begin{tabular}{ccc}
\hline Bulan & Tahun & Hasil Peramalan \\
\hline September & 2020 & Baik \\
Oktober & 2020 & Baik \\
November & 2020 & Baik \\
Desember & 2020 & Baik \\
Januari & 2021 & Baik \\
Februari & 2021 & Baik \\
Maret & 2021 & Baik \\
April & 2021 & Baik \\
Mei & 2021 & Baik \\
Juni & 2021 & Baik \\
Juli & 2021 & Baik \\
Agustus & 2021 & Baik \\
September & 2021 & Baik \\
\hline
\end{tabular}


Lanjutan Tabel 3. Hasil Peramalan Setiap Data Arus Kas

\begin{tabular}{ccc}
\hline Bulan & Tahun & Hasil Peramalan \\
\hline Oktober & 2021 & Baik \\
November & 2021 & Baik \\
Desember & 2021 & Baik \\
\hline
\end{tabular}

Tabel 4. Hasil Peramalan Jumlah Arus Kas

\begin{tabular}{ccc}
\hline Bulan & Tahun & Hasil Peramalan \\
\hline September & 2020 & Baik \\
Oktober & 2020 & Baik \\
November & 2020 & Baik \\
Desember & 2020 & Baik \\
Januari & 2021 & Baik \\
Februari & 2021 & Buruk \\
Maret & 2021 & Baik \\
April & 2021 & Baik \\
Mei & 2021 & Baik \\
Juni & 2021 & Baik \\
Juli & 2021 & Baik
\end{tabular}

\section{Kesimpulan}

Model SVM dengan parameter hasil tuning untuk peramalan data pemasukan operasi menggunakan nilai parameter cost sebesar 4, gamma sebesar 2, dan metode 10 fold cross validation. Sedangkan pada data pengeluaran operasi menggunakan nilai parameter cost sebesar 1024, gamma sebesar 0,125, dan metode 5 fold cross validation. Data pengeluaran investasi menggunakan nilai parameter cost sebesar 128, gamma sebesar 4, dan metode 10 fold cross validation Data arus kas menggunakan nilai parameter cost sebesar 4096, gamma sebesar 0,03125, dan metode 10 fold cross validation. Terdapat perbedaan hasil peramalan arus kas kondisi keuangan PT Cakrawala yaitu menghasilkan kondisi keuangan baik untuk peramalan setiap jenis data arus kas dan menghasilkan kondisi keuangan buruk dalam satu bulan untuk peramalan jumlah data arus kas. 


\section{Daftar Pustaka}

[1] Chapman and Hall. Time-Series Forecasting. United States of America: CRC Press. 2000.

[2] Montgomery, D. C., C. L. Jennings, dan M. Kulahci. Introduction to Time Series Analysis and Forecasting. New Jersey: John Wiley \& Sons, Inc. 2007.

[3] Adhikari, R. An Introductory on Time Series Modeling and Forecasting. Germany: Lambert Academic Publishing. 2013.

[4] Kakani, R. M. and N. Ramachandran. How To Read A Cash Flow Statement. India: Mcgraw Hill Edu Private Limited. 2010.

[5] Han, J., M. Kamber and J. Pei. Data Mining: Concept and Techniques, Third Edition. Waltham: Morgan Kaufmann Publisher. 2012.

[6] Rusdi. Deteksi Stasioneritas Data Runtun Waktu Melalui Uji Akar-Akar Unit. Jurnal Saintek. 3(1): 78-89. 2011.

[7] Karaa dan Krichene. Credit Risk Assessment using Support Vector Machine and Multilayer Neural Network Models: A Comparative Study Case of a Tunisian Bank. Journal of Accounting and Management Information System. 11(4): 587620. 2012.

[8] Karyadiputra, E. dan N. Hijriana. Analisis Penerapan Algoritma Naive Bayes untuk Klasifikasi Prioritas Pengembangan Jalan di Provinsi Kalimantan Selatan. Jurnal Teknologi. 9(2): 105-108. 2018.

[9] Eka, P. Implementasi Support Vector Machine (SVM) pada Prediksi Harga Saham Gabungan (IHSG). Jurnal Teknologi dan Rekayasa. 25(1): 24-38. 2020.

[10] Andita, A. dan W. Sulistijanti. Perbaikan Peramalan Produksi Padi di Kabupaten Kendal dengan Menggunakan Metode Support Vector Machine (SVM). The $7^{\text {th }}$ URECOL2018. 2018. 